\title{
Influence of myocardial infarction on changes in the expression of angiotensin type 1 receptor in the rat prostate
}

\author{
Agnieszka W. Piastowska-Ciesielska ${ }^{1}$, Jacek Drobnik ${ }^{2}$, Joanna Zarzyńska ${ }^{3}$, \\ Kamila Domińska ${ }^{1}$, John A. Russell ${ }^{4}$, Tomasz Ochędalski ${ }^{1}$ \\ ${ }^{1}$ Department of Comparative Endocrinology, Medical University of Lodz, Poland \\ ${ }^{2}$ Department of Connective Tissue Metabolism, Medical University of Lodz, Poland \\ ${ }^{3}$ Department of Food Hygiene and Public Health, Warsaw University of Life Sciences, Poland \\ ${ }^{4}$ Centre for Integrative Physiology, CMVM, University of Edinburgh, UK
}

\begin{abstract}
Angiotensin II (AngII) is the biologically active peptide of the renin-angiotensin system (RAS). Tissue-based, local RAS has been identified in the prostate, testis, epididymis and coagulating glands. Experimental and clinical studies have consistently shown that myocardial infarction (MI) is associated with activation of the systemic RAS with increased concentration of angiotensin peptides in the blood and changes in expression of angiotensin receptors (AT). Changes in angiotensin receptors in the renal and cardiovascular system after MI are well recognized, but the effects of MI influence on changes in other tissue like the prostate gland are unknown. In the present study, we investigated the effect of myocardial infarction on angiotensin receptor protein and mRNA expression in the rat prostate gland. MI model was established in Wistar rats by ligating the left coronary artery (modified Selye method). The levels of ATla-b and AT2 receptor mRNAs and proteins were measured in the rat prostate. Our study demonstrates tissue-specific changes in ATla-b and AT2 receptor expression after myocardial infarction. The results show that MI has a strong influence on the expression of angiotensin receptor type ATl in the prostate at the protein and mRNA level. (Folia Histochemica et Cytobiologica 2011, Vol. 49, No. 3, 497-503)
\end{abstract}

Key words: angiotensin receptor, myocardial infarction, prostate, rat

\section{Introduction}

Angiotensin II (AngII), the biologically active peptide of the renin-angiotensin system (RAS), is a major regulator of blood pressure and cardiovascular homeostasis, and is also recognized as a potent mitogen $[1,2]$. Tissue-based, local RAS components have been identified in the prostate, testis, epididymis, coagulating glands, ovary, uterus, placenta, brain, heart,

Correspondence address: A.W. Piastowska-Ciesielska,

Department of Comparative Endocrinology,

Medical University of Lodz,

Zeligowskiego Str. 7/9, 90-752 Lodz, Poland; tel.: (+ 48 42) 63931 80, fax: (+ 48 42) 6779318

e-mail: agnieszka.piastowska@umed.lodz.pl peripheral blood vessels, adrenal glands, and kidney $[3,4]$. The ability of RAS sites in the testis, epididymis and prostate to synthesize AngII have been reported in recent years [4-6]. AngII concentrations in the seminal plasma are three to five times higher than in blood plasma. This information may indicate an important role for the RAS in the prostate. Heart failure and myocardial infarction are progressive disorders in which damage to the heart causes weakening of the cardiovascular system. It is manifested by fluid congestion or inadequate blood flow to tissues. A myocardial infarction initiates in the heart a sequence of humoral, neurogenic and hemodynamic events which influence the function of the heart and of remote organs. This progressive disorder must be man- 
aged with regard to not only the state of the heart, but the condition of the circulation, lungs, neuroendocrine system and perhaps other organs like the prostate as well [7, 8]. Several experimental and clinical studies have consistently shown that a myocardial infarction is associated with activation of the systemic RAS, and consequently increased concentration of angiotensin peptides in the blood and changes in angiotensin receptors (AT) expression [7, 9]. The physiological actions of the bioactive angiotensin peptides depend on their chemical structure and on their specificity for the membrane receptors, the information transducers at the cellular level $[10,11]$. AngII is the first, and the most active, multifunctional hormone of the RAS [12]. Its interactions with the specific angiotensin receptors trigger complex cellular signaling events, which have been extensively studied in various organs and anatomical structures [13].

It is well known that AngII is a pivotal factor in the RAS, and increases blood pressure in the systemic and local blood circulation. In particular, this peptide affects the kidney and stimulates aldosterone release from the adrenal gland [14, 15]. It is also now known that AngII plays a key role in cardiac hypertrophy, heart failure, atherosclerosis and remodeling $[16,17]$. This confirms the hypothesis that the RAS is expressed locally and that AngII directly functions as a pathophysiological factor in cardiovascular and renal diseases [18]. In mammalian cells, AngII binds to two distinct high-affinity plasma membrane receptors, ATl and AT2. Two subtypes of the ATl receptor (ATla and ATlb) have been identified in rodents, but not in humans $[12,13]$. ATl receptor activation leads to vascular contraction, inflammatory responses, salt and water retention, and cell proliferation, whereas the AT2 receptor induces apoptosis, vasodilation and natriuresis. In the vasculature, AT1 receptors are expressed in the smooth muscle cells, while in the human prostate, autoradiography and immunohistochemistry show that ATl receptors are localized to stromal smooth muscle, confirmed by staining for smooth muscle actin [19]. At these levels, AngII promotes its effects via angiotensin receptors, which trigger intracellular signaling processes, including crosstalk with pathways activated by other vasoactive agents, and are accompanied by the release of other bioactive factors. In response to AngII stimulation, AT1 receptors interact with various heterotrimeric G proteins inducing the phosphorylation of tyrosine-kinases [20]. Binding of AngII to ATl receptor results in internalization of the ATl-AngII complex. While the receptor is recycled back to the plasma membrane, AngII is destined for intracellular locations such as lysosomes and the nucleus $[13,21]$. The intracellular signaling processes are multiphasic, leading to various biological actions. The AT1-receptor activation leads to increased protein tyrosine phosphorylation and to the activation of mitogen-activated protein-kinase (MAPK). These processes are associated with growth factors and cytokines as pleiotropic and inflammatory agents. Thus, in addition to its potent vasoconstrictor actions, AngII has proliferative and proinflammatory properties $[11,22]$. There are a few possible functions for the AT1 receptor in the different prostatic cell types. The presence of AT1 receptors is highly characteristic of many secretory epithelia, including in the fallopian tube, renal proximal tubule or pancreas $[5,23,24]$. The presence of the ATl receptor in vascular smooth muscle cells may suggest that AngII is able to contribute to regulating prostatic blood flow and the presence of these receptors in the stromal smooth muscle cells may have a role in modulating muscle tone, cell growth and control of migration [25].

Uemura et al. demonstrated that activation of AT1receptors in LNCaP, DU145 and PrSC cells stimulates mitogen activated protein kinase (MAPK), Janus tyrosine kinase-signal transducers, activators of transcription (STAT), and cell proliferation [26-28]. Many studies confirm that AngII acting via the AT1 receptor may have a role in the development and progression of prostate cancer [27, 29-31]. Other experiments support the hypothesis that prostatic stromal cells are involved in the promotion of growth factor activity, and may contribute to the initiation and development of prostate cancer [3, 27, 30, 32]. Whereas changes in angiotensin receptor expression in the renal and cardiovascular systems after myocardial infarction are well recognized, the effects of myocardial infarction on changes in other tissue like the prostate gland are not known. In the present study, we investigated the effect of myocardial infarction on angiotensin receptor expression at the level of protein and mRNA expression in the rat prostate gland.

\section{Material and methods}

Ethical considerations. All experimental procedures involving the animals were approved by the Local Committee for Ethics in Animal Experimentation of the Medical University of Lodz, Poland. The experiments were performed in accordance with the Committee's guidelines.

Animals. Adult Wistar rats weighing $260 \mathrm{~g} \pm 30 \mathrm{~g}$ (mean \pm \pm SEM) were housed with free access to commercial food pellets (LSM), as well as tap water ad libitum. All the rats were kept in 12 h:12 h Light-Dark (LD) conditions. Rats were divided into two groups: 1) controls (C) composed of 
sham operated rats, 2) animals with myocardial infarction (MI) induced by ligation of the left coronary artery. Each group contained ten rats, not older than five months. Twenty eight days after ligation of the coronary artery, the rats were killed under ether anesthesia and the prostate glands were removed and dissected. One lobe of the ventral prostate was formalin-fixed and paraffin-embedded for histological and immunohistochemical studies. Another lobe was frozen in liquid nitrogen and kept at $-80^{\circ} \mathrm{C}$ until RNA isolation and Western-blot analysis.

Myocardial infarction model. Left coronary artery ligation was performed according to the Selye method with our modification [33]. To prevent ventricular arrhythmias, all rats were treated with $2 \mathrm{mg} / \mathrm{kg}$ of lignocaine intraperitoneally (i.p.). The rats were anesthetized with pentobarbital at the dose of $50 \mathrm{mg} / \mathrm{kg}$ i.p. and ventilated with positive pressure through a tube inserted into the trachea and connected to a small animal respirator (Kent Scientific Corporation, RSP1002). A $2 \mathrm{~cm}$ long craniocaudal incision of the skin and pectoral muscles was made and then the intercostal muscles were cut between the fifth and sixth ribs. After opening the pericardium, the heart was gently exteriorized and the left coronary artery was ligated with $6 / 0$ nylon sutures. The ligation was made between the left margin of the pulmonary cone and the closest point of insertion of the left auricular appendage. The heart was returned to the thorax and after closing the muscles and the skin, the lungs were expanded. The sham operation comprised the same surgical procedure, but the left coronary artery was not ligated. After surgery, all animals were injected with penicillin (200,000 units/animal). After four weeks, all rats were killed humanely, and their prostate glands and hearts were obtained.

Immunohistochemistry. The prostate glands were histologically analyzed by standard methods. 5 - $\mu \mathrm{m}$-thick sections were cut and placed on glass slides and stained with hematoxylin and eosin for identification of histologically distinct tissue regions. ATl immunostaining was performed using the anti-AT1 polyclonal antibody sc-1173 (Santa Cruz Biotechnology). This antibody was raised against the N-terminal extracellular domain of the ATl receptor and recognizes human, rat and mouse receptor protein. AT2 receptors were revealed using the sc-9040 (Santa Cruz Biotechnology) polyclonal antibody raised against the 221-303 fragment of the AT2 receptor protein. The antibody detects human, rat and mouse AT2 receptors. The anti-AT1 and anti-AT2 antibodies were applied in a working dilution of 1:100. The visualization of primary anti-receptor antibodies was done using the StreptABComplex/HRP Duet (Dako) following the procedure recommended by the manufacturer. In brief, a biotinylated goat antibody against rabbit and mouse immunoglobulin was applied as the secondary antibody, fol- lowed by streptavidin-biotinylated horseradish peroxidase complex and 3,3'-diaminobenzidine as chromogen. The slides were analyzed in a light microscope (Olympus Optical Co. Ltd.). The evaluation procedure was performed using MICRO IMAGE ${ }^{\mathrm{TM}}$ software (Olympus Optical Co. Ltd.). The optical density (OD), calculated by multiplication of the area of cell labeling and density, was used for evaluation of receptor expression. At least 20 randomly chosen visual fields per slide were examined.

Immunoblotting. Total protein from frozen prostate tissues was extracted in RIPA protein extraction buffer consisting of $50 \mathrm{mM}$ Tris $\mathrm{HCl}$ (pH 8.0), $150 \mathrm{mM} \mathrm{NaCl}, 0.5 \% \mathrm{Na}$ Doc, $0.1 \%$ NP-40, 0.1\% SDS, 2 mM EDTA, supplemented with protease and phosphatase Inhibitor Cocktail (Sigma-Aldrich P8340, P6726) and $1 \mathrm{mM}$ PMSF. The lysate was centrifuged at $14,000 \times \mathrm{g}$ and $4^{\circ} \mathrm{C}$ for $20 \mathrm{~min}$, and the pellet discarded. Protein concentrations were determined by the method of Bradford (Bio-Rad Laboratories, Hercules, CA, USA) according to the manufacturer's protocol and using bovine serum albumin as a standard. Tissue homogenates were mixed in a 3:1 ratio with 4-fold concentrated Laemmli buffer (Bromophenol blue, 40\% glycerol, 8-10\% SDS, $20 \%$ $\beta$-mercaptoethanol), heated for $2-5 \mathrm{~min}$ at $100^{\circ} \mathrm{C}$ and deposited on the gel at $50 \mathrm{mg}$ of protein per track. Protein samples were subjected to $10 \%$ SDS-PAGE and electrophoretically transferred to a PVDF membrane (Sigma-Aldrich P2938). The membrane was preincubated in 5\% non-fat milk in TBST (20 mM Tris-HCL, $500 \mathrm{mM} \mathrm{NaCl}, 0.05 \%$ Tween-20, $\mathrm{pH} 7.5$ ) for 1 hour at room temperature. After this time, the membranes were incubated for $12 \mathrm{~h}$ at $4^{\circ} \mathrm{C}$ with the addition of selected primary antibodies (Santa Cruz Biotechnology Inc.). At the end of the overnight incubation, the membrane was washed three times $(3 \times 15 \mathrm{~min})$ with TBST and incubated for one hour in a solution of $5 \%$ milk powder in TBST containing the appropriate secondary antibodies conjugated with horseradish peroxidase (Santa Cruz Biotechnology Inc.). After incubation with secondary antibodies, the membrane was washed three times $(3 \times 15 \mathrm{~min})$ in TBST buffer. The chemiluminescent reaction was induced using ECL (GE Healthcare UK Ltd). Bands were visualized by capture on X-ray film. Densitometric analysis of protein levels was performed with ImageJ 1.34s software (Wayne Rasband, National Institutes of Health, USA; http://rsb.info.nih.gov) and the results were expressed as optical density (OD). The results were normalized for GAPDH OD.

Reverse transcription Polymerase Chain Reaction. Total RNA was extracted from rat prostate homogenates using the RNeasy mini kit (Qiagen Ltd., West Sussex, UK). RT-PCR primers were designed from mRNA sequences published in NCBI, with the Primer3 program (http://frodo.wi.mit.edu/primer3/), Table 1. Primers were syn- 
Table 1. Primer sequences used for ATla, AT1b, AT2 receptor and GAPDH

\begin{tabular}{|l|c|c|c|}
\hline Gene name & $\begin{array}{c}\text { Gen Bank } \\
\text { accession number }\end{array}$ & \multicolumn{1}{c|}{$\begin{array}{c}\text { Primer } \\
\text { sequences }\end{array}$} & $\begin{array}{c}\text { Product size } \\
\text { (bp) }\end{array}$ \\
\hline Angiotensin II receptor, type 1a [Rattus norvegicus] & 24180 & $\begin{array}{c}\text { 5'-GGAAACAGCTTGGTGGTGAT-3' } \\
\text { 5'-ACATAGGTGATTGCCGAAGG-3' }\end{array}$ & 171 \\
\hline Angiotensin II receptor, type 1b [Rattus norvegicus] & 81638 & $\begin{array}{c}\text { 5'-GGAAACAGCTTGGTGGTGAT-3' } \\
\text { 5'-GCTGGCAGAAGCGATCTTAC-3' }\end{array}$ & 189 \\
\hline Angiotensin II receptor, type 2 [Rattus norvegicus] & 24182 & $\begin{array}{l}\text { 5'-AACCGGCAGATAAGCATTTG-3' } \\
\text { 5'-AAGTCAGCCACAGCCAGATT-3' }\end{array}$ & 160 \\
\hline $\begin{array}{l}\text { Glyceraldehyde-3-phosphate dehydrogenase } \\
\text { [Rattus norvegicus] }\end{array}$ & 24383 & $\begin{array}{l}\text { 5'-ATGGGAAGCTGGTCATCAAC-3' } \\
\text { 5'-GTGGTTCACACCCATCACAA-3' }\end{array}$ & 221 \\
\hline
\end{tabular}

thesized in the Oligo IBB PAN (Institute of Biochemistry and Biophysics, Poland). RT-PCR was carried out from $1 \mu \mathrm{g}$ total RNA with reagents from the Access RT-PCR System kit (Promega, UK), following the manufacturer's instructions. PCR products were separated on $1.5 \%$ agarose gels and visualized under UV light. Densitometric analysis of each band was performed with ImageJ $1.34 \mathrm{~s}$ software (Wayne Rasband, National Institutes of Health, USA) and the results were expressed as optical density (OD). GAP$\mathrm{DH}$ was used as an internal standard. The densitometry values were normalized against the GAPDH values and expressed as band OD compared to the control group.

Statistical analysis was performed with GraphPad Prism 4 software (GraphPad Software, Inc). All results are expressed as mean values \pm SEM. $t$-test, one-way ANOVA and Newman-Keuls test were employed to determine significant differences, with an accepted level of significance of $p<0.05$.

\section{Results}

\section{Determination of infarct sizes}

To evaluate whether myocardial infarctions were of similar extent among rats, the infarct sizes were micromorphometrically evaluated. The hearts were divided into the left ventricle, right ventricle, scar and septum, then the weight of all parts was measured. The mean scar weight was $34.7 \pm 14.5 \mathrm{mg} / 100 \mathrm{~g}$ b.w. The ratio of the surface area of the scar to the wall of the left ventricle was mean $37.7 \% \pm 6.9 \%$.

\section{Angiotensin receptor level in the prostate}

\section{Immunohistochemistry}

Twenty eight days after surgery, a statistically significant increase in the number of AT1 receptors was observed by immunohistochemical staining of rat prostate sections. The mean OD value for AT1 receptor in the epithelium in the control group of rats was $58.66 \pm 6.09$ and for the infarct group $198.4 \pm$ $\pm 31.69(\mathrm{p}<0.01)$. For the stroma, these values were $242.2 \pm 28.61$ (control group), and for the infarct
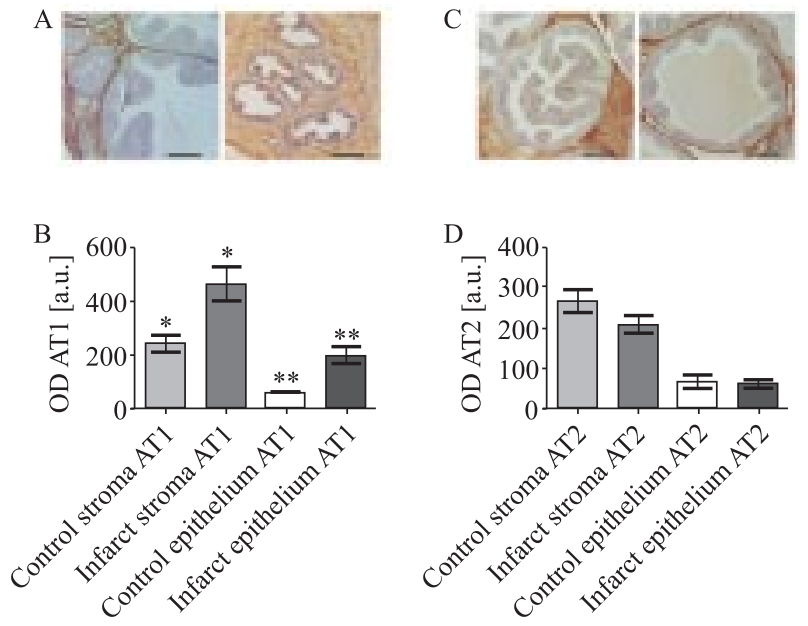

Figure 1. Immunocytochemistry of rat prostate sections using the anti AT1 and AT2 monoclonal antibody. Localization of antigens is indicated by brown staining $(\mathbf{A}, \mathbf{C})$. The scale bars are $100 \mu \mathrm{m}$. The histograms represent the mean value optical densities (OD) of AT1 (B) and AT2 (D). The OD intensity is given on an arbitrary scale in arbitrary units [a.u.]. Asterisk indicates significant differences $\left({ }^{*} \mathrm{p}<0.05 ;{ }^{* *} \mathrm{p}<0.01\right)($ mean \pm SEM) compared to controls

group $465.5 \pm 66(\mathrm{p}<0.05)$. In the epithelium, the density of AT1 receptors was increased by 3.38-fold compared to the control group. In the stroma, it was increased by 1.9 fold $(\mathrm{p}<0.05)$ compared to the control group (Figure 1 panels $\mathrm{A}$ and $\mathrm{B}$ ).

In the case of AT2 receptors, we observed a decrease in the density of the receptors of 0.95 -fold in the epithelium and 0.78-fold in the stroma. Mean OD value for the AT2 receptor in the control group was $63.85 \pm 17$ in the epithelium and $264.3 \pm 32.05$ in the stroma. In the infarct group, the mean OD value for the epithelium was $61.13 \pm 10.45$ and $206.7 \pm 21.67$ for the stroma. The respective values were not significantly different (Figure 1 panels $\mathrm{C}$ and $\mathrm{D}$ ).

\section{Immunoblotting assay}

Immunoblotting assay showed that the total quantity of AT1 receptor protein was greater in rats with myo- 
A

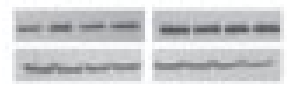

B

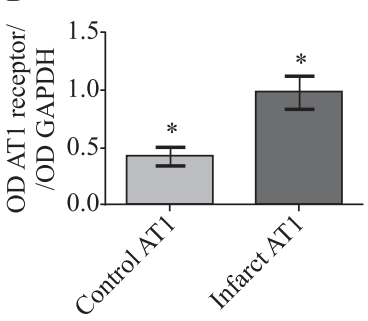

D

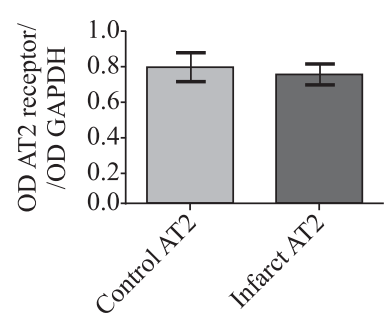

Figure 2. Effects of myocardial infarction on the expression of AT1 and AT2 receptor protein in rat prostate. Upper panels $(\mathbf{A}, \mathbf{C})$ present representative Western-blot of AT1 (A) and AT2 (C) receptor protein. Histograms B and $\mathbf{D}$ represent the mean value ratio of optical densities (OD) of AT receptor protein/GAPDH. Asterisk indicates significant differences $(* p<0.05)$ (mean \pm SEM) compared to controls

cardial infarction. Mean optical density value for AT1 normalized for GAPDH optical density in the control group was $0.42 \pm 0.07$ and in the infarct group $0.97 \pm 0.14(\mathrm{p}<0.05)$. This increase was 2.3 -fold and statistically significant (Figures $2 \mathrm{~A}$ and B). In the case of the AT2 receptor protein, a decrease in AT2 receptor protein $0.93 \pm 0.13$ times was observed. Mean OD value for AT2 normalized for GAPDH in the control group was $0.80 \pm 0.08$ and in the infarct group $0.74 \pm 0.06$. These values were not statistically significant (Figures $2 \mathrm{C}$ and D).

Reverse transcription Polymerase Chain Reaction for $A T 1$ receptor and AT2 receptor $m R N A$ in the rat prostate The effects of myocardial infarction on mRNA expression for ATla and ATlb receptors in the prostate are shown in Figure 3. Gel electrophoresis of PCR products show there was an increase in the mRNA level of both the ATla and ATlb receptors (9.3 and 7.9-fold, respectively) in the MI group compared to the control group. The observed increase was statistically significant for both AT1 receptors ( $p<0.05$; $\mathrm{p}<0.01$ ). The level of AT2 receptor mRNA was 0.89 -fold lower after myocardial infarction, but there was no statistically significant difference in the level of AT2 mRNA between the groups.

\section{Discussion}

The present study demonstrates tissue-specific changes in expression of AT1 and AT2 receptor after myocardial infarction (MI). The results show that MI has an evident influence on the expression of angiotensin
A

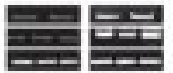

C

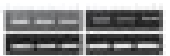

$\mathrm{B}$
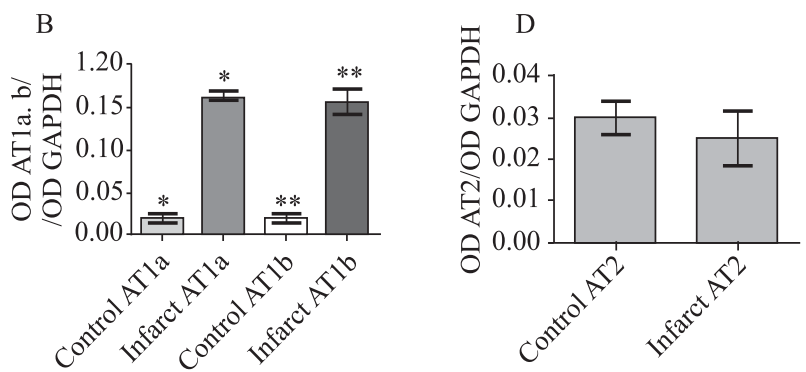

Figure 3. RT-PCR demonstrated expression level of angiotensin receptor mRNA in rat prostate. Upper panels (A, C) present representative bands of ATla, ATlb mRNA (A) and AT2 mRNA (C). Left part of panels A and C presents Control group, right part Infarct group. The histograms $\mathbf{B}$ and $\mathbf{D}$ represent the mean value of AT mRNA OD. Asterisk indicates significant differences $(* \mathrm{p}<0.05$; $* * p<0.01)($ mean \pm SEM) compared to controls

receptor type 1 (AT1) in prostate tissue. These changes comprise both protein and mRNA level.

Numerous studies have shown that MI has a significant impact on changes in the RAS system components, such as expression of angiotensin receptors, or angiotensin-converting enzyme activity in various tissues [7, 34-36]. In vivo and in vitro experiments have shown that MI provokes a dramatic up-regulation of both angiotensin receptor subtypes in different organs $[34,37,38]$. Busche et al. have shown that cardiomyocytes express AT1 and AT2 receptor mRNA under physiological conditions, but the number of cells expressing these receptors is not increased after myocardial infarction [34]. In another study performed on rats, Tan et al. observed that after MI there is a significant increase in AT1 receptor and ACE densities, not only in the heart, but also in brain nuclei [39]. Also experiments by Milik et al. demonstrated a significant increase of ATla mRNA in the heart and kidney after MI, thereby suggesting that the myocardial infarct initiates in these organs the processes which may finally result in increased synthesis of ATla receptor protein [7].

Although AngII is well known to be an important factor in hypertension, it has also been reported to play a central role in proliferation and/or differentiation via ATl receptor in specific organs, linking it to the progression of cancer [40]. Changes in RAS components have been identified in various cancer types in humans and animals, and it has been reported that the AT1 receptor is involved in the proliferation of various cancers in vitro and in vivo [26, 41-43]. Studies by Suganuma [44] showed that AT1 receptor ex- 
pression was dramatically up-regulated during the progression from benign to malignant phenotypes of ovarian tumors. ATl was expressed in $85 \%$ of invasive ovarian carcinomas and was not dependent on the histopathologic subtype. Marsigliante et al. showed that the human larynx expresses the AT1 receptor type, and that it is dramatically increased in well differentiated cancer cells [45]. Studies of cervical carcinoma cells demonstrated that the AT1 receptor is present in these cells and that AngII enhances invasive potency by increasing the secretion of vascular endothelial growth factor (VEGF) through the AT1 receptor. Angiotensin activity mediated via AT1 receptor is also involved in the progression of cervical carcinoma, as it induces the secretion of VEGF, which results in the increased invasiveness of carcinoma cells [46]. Uemura et al. presented strong evidence of the influence of AngII and ATl receptor blockers on prostate cancer cells and tumor growth of prostate cancer [18]. They noted that AngII enhances proliferation of prostate cancer cells via signaling pathway that includes activation of ATl receptor MAPK and STAT3. Moreover, the cell proliferation induced by AngII was similar in androgen-dependent and androgen-independent cancer cells (LNCaP and DU145). Expression of AT1 receptor protein in the normal human prostate and benign prostatic hyperplasia is localized on stromal smooth muscle, while AngII peptide is localized in the basal layer of the epithelium, suggesting that AngII is mediating cellular growth and smooth muscle tone in the human prostate in a paracrine manner [25].

These preliminary results indicate that $\mathrm{MI}$ is a factor which could provoke the changes in ATl receptor expression in prostate tissue. Based on the observations of other authors, we can suppose that an increase in the number of ATl receptors may cause excessive cell proliferation [40, 47].

It seems that increasing the number of receptors in the stroma could be a key factor for the future cause of neoplastic lesions of the prostate. Cell proliferation can be activated by angiotensin II in two ways: directly and indirectly. The direct way involves the mechanism of activating the AngII via ATl receptor. The indirect activation starts with the AT1 receptor (activated by angiotensin), which mediates the intracellular signal regulating the androgen receptors, which are responsible for cell proliferation or hypertrophy.

It is very probable that changes in the balance between AT1 and AT2 receptors in the prostate gland, which occur as a result of a myocardial infarction, may be the cause of hypertrophy of the prostate. We cannot exclude that the far-reaching consequence of the imbalance of homeostasis can be the process of carcinogenesis in this tissue. In conclusion, it seems essential to pay greater attention to the consequences of cardiovascular failure in the context of distant tissues such as the prostate.

\section{Acknowledgements}

This work was supported by Medical University of Lodz (grant numbers 502-19-681); Ministry of Science and Higher Education (grant numbers N404 $107733)$.

\section{References}

1. Deshayes F, Nahmias C. Angiotensin receptors: a new role in cancer? Trends Endocrinol Metab. 2005;16:293-299.

2. Zhu YC, Zhu YZ, Lu N, Wang MJ, Wang YX, Yao T. Role of angiotensin AT1 and AT2 receptors in cardiac hypertrophy and cardiac remodelling. Clin Exp Pharmacol Physiol. 2003;30:911-918.

3. Chow L, Rezmann L, Catt KJ et al. Role of the renin-angiotensin system in prostate cancer. Mol Cell Endocrinol. 2009;302:219-229.

4. Leung PS, Sernia C. The renin-angiotensin system and male reproduction: new functions for old hormones. J Mol Endocrinol. 2003;30:263-270.

5. O'Mahony OA, Barker S, Puddefoot JR, Vinson GP. Synthesis and secretion of angiotensin II by the prostate gland in vitro. Endocrinology. 2005;146:392-398.

6. Chow L, Rezmann L, Catt KJ et al. Role of the renin-angiotensin system in prostate cancer. Mol Cell Endocrinol. 2009;302:219-229.

7. Milik E, Szczepanska-Sadowska E, Cudnoch-Jedrzejewska A, Dobruch J, Morton M, Koperski L. Upregulation of angiotensin ATla receptors mRNA in the heart and renal medulla after myocardial infarction in rats. $J$ Physiol Pharmacol. 2006;57:375-388.

8. Watson AM, Hood SG, May CN. Mechanisms of sympathetic activation in heart failure. Clin Exp Pharmacol Physiol. 2006;33:1269-1274.

9. Pretorius L, Owen KL, Jennings GL, McMullen JR. Promoting physiological hypertrophy in the failing heart. Clin Exp Pharmacol Physiol. 2008;35:438-441.

10. Greco S, Muscella A, Elia MG et al. Angiotensin II activates extracellular signal regulated kinases via protein kinase $\mathrm{C}$ and epidermal growth factor receptor in breast cancer cells. J Cell Physiol. 2003;196:370-377.

11. McWhinney CD, Dostal D, Baker K. Angiotensin II activates Stat5 through Jak2 kinase in cardiac myocytes. $J$ Mol Cell Cardiol. 1998;30:751-761.

12. Haulica I, Bild W, Serban DN. Angiotensin peptides and their pleiotropic actions. J Renin Angiotensin Aldosterone Syst. 2005;6:121-131.

13. Unger T, Chung O, Csikos $\mathrm{T}$ et al. Angiotensin receptors. J Hypertens Suppl 1996;14:S95-103.

14. Uemura H, Ishiguro $\mathrm{H}$, Kubota $\mathrm{Y}$. Angiotensin II receptor blocker: possibility of antitumor agent for prostate cancer. Mini Rev Med Chem. 2006;6:835-844.

15. Natarajan R, Kathuria S, Lanting L, Gonzales N, Nadler J. Differential short- and long-term effects of insulin on ANG II action in human adrenal glomerulosa cells. Am J Physiol. 1995;268:E100-E106. 
16. Porter KE, Turner NA. Cardiac fibroblasts: at the heart of myocardial remodeling. Pharmacol Ther. 2009;123:255-278.

17. Huang BS, Ahmad M, Tan J, Leenen FH. Chronic central versus systemic blockade of AT(1) receptors and cardiac dysfunction in rats post-myocardial infarction. Am $J$ Physiol Heart Circ Physiol. 2009;297:H968-H975.

18. Uemura H, Ishiguro H, Kubota Y. Pharmacology and new perspectives of angiotensin II receptor blocker in prostate cancer treatment. Int J Urol. 2008;15:19-26.

19. Dinh DT, Frauman AG, Sourial M, Casley DJ, Johnston CI, Fabiani ME. Identification, distribution, and expression of angiotensin II receptors in the normal human prostate and benign prostatic hyperplasia. Endocrinology. 2001;142:1349-1356 .

20. Touyz RM, Berry C. Recent advances in angiotensin II signaling. Braz J Med Biol Res. 2002;35:1001-1015.

21. Baker KM, Kumar R. Intracellular angiotensin II induces cell proliferation independent of ATl receptor. Am J Physiol Cell Physiol. 2006;291:C995-1001.

22. Earp HS, Huckle WR, Dawson TL, Li X, Graves LM, Dy R. Angiotensin II activates at least two tyrosine kinases in rat liver epithelial cells. Separation of the major calcium-regulated tyrosine kinase from p125FAK. J Biol Chem. 1995;270: 28440-28447.

23. Vinson GP, Ho MM, Puddefoot JR. The distribution of angiotensin II type 1 receptors, and the tissue renin-angiotensin systems. Mol Med Today. 1995;1:35-39.

24. Cheng HF, Becker BN, Burns KD, Harris RC. Angiotensin II upregulates type-1 angiotensin II receptors in renal proximal tubule. J Clin Invest. 1995;95:2012-2019.

25. Dinh DT, Frauman AG, Somers GR et al. Evidence for activation of the renin-angiotensin system in the human prostate: increased angiotensin II and reduced AT(1) receptor expression in benign prostatic hyperplasia. $J$ Pathol. 2002; 196:213-219.

26. Uemura $\mathrm{H}$, Ishiguro $\mathrm{H}$, Nakaigawa $\mathrm{N}$ et al. Angiotensin II receptor blocker shows antiproliferative activity in prostate cancer cells: a possibility of tyrosine kinase inhibitor of growth factor. Mol Cancer Ther. 2003;2:1139-1147.

27. Uemura $\mathrm{H}$, Ishiguro $\mathrm{H}$, Nagashima $\mathrm{Y}$ et al. Antiproliferative activity of angiotensin II receptor blocker through cross-talk between stromal and epithelial prostate cancer cells. $\mathrm{Mol}$ Cancer Ther. 2005;4:1699-1709.

28. Uemura $\mathrm{H}$, Nakaigawa $\mathrm{N}$, Ishiguro $\mathrm{H}$, Kubota $\mathrm{Y}$. Antiproliferative efficacy of angiotensin II receptor blockers in prostate cancer. Curr Cancer Drug Targets. 2005;5:307-323.

29. Wennemuth G, Aumuller G. Angiotensin II-mediated calcium signals and mitogenesis in human prostate stromal cell line hPCPs. Br J Pharmacol. 2005;144:3-10.

30. Chow L, Rezmann L, Imamura $\mathrm{K}$ et al. Functional angiotensin II type 2 receptors inhibit growth factor signaling in LNCaP and PC3 prostate cancer cell lines. Prostate. 2008; 68:651-660.

31. Ishiguro H, Ishiguro Y, Kubota Y, Uemura H. Regulation of prostate cancer cell growth and PSA expression by angiotensin II receptor blocker with peroxisome proliferatoractivated receptor gamma ligand like action. Prostate. 2007;67:924-932.

32. Tuxhorn JA, McAlhany SJ, Yang F, Dang TD, Rowley DR. Inhibition of transforming growth factor-beta activity decreas- es angiogenesis in a human prostate cancer-reactive stroma xenograft model. Cancer Res. 2002;62:6021-6025.

33. Drobnik J, Karbownik-Lewinska M, Szczepanowska A et al. Regulatory influence of melatonin on collagen accumulation in the infarcted heart scar. J Pineal Res. 2008;45:285-290.

34. Busche S, Gallinat S, Bohle RM et al. Expression of angiotensin AT(1) and AT(2) receptors in adult rat cardiomyocytes after myocardial infarction. A single-cell reverse transcriptase-polymerase chain reaction study. Am J Pathol. 2000;157:605-611.

35. Pieruzzi F, Abassi ZA, Keiser HR. Expression of renin-angiotensin system components in the heart, kidneys, and lungs of rats with experimental heart failure. Circulation. 1995; 92:3105-3112.

36. Schunkert $\mathrm{H}$, Ingelfinger JR, Hirsch AT et al. Evidence for tissue-specific activation of renal angiotensinogen mRNA expression in chronic stable experimental heart failure. JClin Invest. 1992;90:1523-1529.

37. Zhu YZ, Zhu YC, Li J et al. Effects of losartan on haemodynamic parameters and angiotensin receptor mRNA levels in rat heart after myocardial infarction. $J$ Renin Angiotensin Aldosterone Syst. 2000;1:257-262.

38. Paradis P, Dali-Youcef N, Paradis FW, Thibault G, Nemer M. Overexpression of angiotensin II type I receptor in cardiomyocytes induces cardiac hypertrophy and remodeling. Proc Natl Acad Sci USA 2000;97:931-936.

39. Tan J, Wang H, Leenen FH. Increases in brain and cardiac ATl receptor and ACE densities after myocardial infarct in rats. Am J Physiol Heart Circ Physiol. 2004;286:1665-1671.

40. Hoshino K, Ishiguro H, Teranishi JI et al. Regulation of androgen receptor expression through angiotensin II type 1 receptor in prostate cancer cells. Prostate. 2010;71:964-975 .

41. Fujimoto Y, Sasaki T, Tsuchida A, Chayama K. Angiotensin II type 1 receptor expression in human pancreatic cancer and growth inhibition by angiotensin II type 1 receptor antagonist. FEBS Lett. 2001;495:197-200.

42. Rivera E, Arrieta O, Guevara P, Duarte-Rojo A, Sotelo J. ATl receptor is present in glioma cells; its blockage reduces the growth of rat glioma. Br J Cancer. 2001;85:1396-1399.

43. Muscella A, Greco S, Elia MG, Storelli C, Marsigliante S. Angiotensin II stimulation of $\mathrm{Na}^{+} / \mathrm{K}^{+}$ATPase activity and cell growth by calcium-independent pathway in MCF-7 breast cancer cells. J Endocrinol. 2002;173:315-323.

44. Suganuma T, Ino K, Shibata K et al. Functional expression of the angiotensin II type 1 receptor in human ovarian carcinoma cells and its blockade therapy resulting in suppression of tumor invasion, angiogenesis, and peritoneal dissemination. Clin Cancer Res. 2005;11:2686-2694.

45. Marsigliante S, Resta L, Muscella A, Vinson GP, Marzullo A, Storelli C. ATl angiotensin II receptor subtype in the human larynx and squamous laryngeal carcinoma. Cancer Lett. 1996;110:19-27.

46. Kikkawa F, Mizuno M, Shibata $\mathrm{K}$ et al. Activation of invasiveness of cervical carcinoma cells by angiotensin II. Am J Obstet Gynecol. 2004;190:1258-1263.

47. Arnold JT, Gray NE, Jacobowitz K et al. Human prostate stromal cells stimulate increased PSA production in DHEAtreated prostate cancer epithelial cells. $J$ Steroid Biochem Mol Biol. 2008;111:240-246. 